\title{
Academic Activities after School That Help Secondary School Children's Cognitive Development through Hermeneutic Analysis
}

\author{
Suppiah Nachiappan ${ }^{1}$, Veeramani Marimuthu ${ }^{1}$, Hari Krishnan Andi ${ }^{1} \&$ Velayudhan P. K. Veeran ${ }^{1}$ \\ ${ }^{1}$ Faculty of Education \& Human Development, Sultan Idris Education University, Malaysia \\ Correspondence: Suppiah Nachiappan, Faculty of Education \& Human Development, Sultan Idris University, \\ Malaysia. Tel: 60-12-527-0801. E-mail: suppiah@fppm.upsi.edu.my
}

Received: April 8, $2012 \quad$ Accepted: May 15, $2012 \quad$ Published: August 1, 2012

doi:10.5539/ass.v8n10p223 URL: http://dx.doi.org/10.5539/ass.v8n10p223

\begin{abstract}
This research is an effort to look into academic activities after school that help secondary school students in cognition development through Hermeneutic analyse for students of Pantai Remis Secondary School, Perak. This research is also to show that Hermeneutic understanding method can be applied effectively to identify academic activities after school that help secondary school students in their cognition development. This research involved 20 secondary school students from Form 1 to Form 3. They were asked to write a reflective essay about academic activities that they did after school hours. Their reflective essays were made a research text that will be using Hermeneutic analyse to find out academic activities that help their cognition development. This research shows that if a student can do positive activities after school such as doing revision, going for tuition, attending classes, doing homework, studying at home, doing module paper, involving school work, carrying out exercises, attending extra classes, involving in ritual study, going to class and attending study with teacher, involving in preparation class, doing mathematic exercises, reading, doing notes, going to library to study, reading geography, reading notes from internet, watching Astro channel that shows education programmes and reading books, thus they can help their cognition development and become excellent students in academic.
\end{abstract}

Keywords: cognition development, secondary school, academic activities, Hermeneutic analysis, after-school

\section{Introduction}

Education system in Malaysia has made children from the age of 6 to attend school. They will start from kindergarten and go on to high school and universities. Children will start to learn from 7.30 in the morning and will end at $1.00 \mathrm{pm}$. After that, they will have extra curricular activities to gain more knowledge. Activities are tasks or actions carried out in addition to subject and give wisdom and knowledge to students (Kamus Dewan, 2005). After-school activity means any activity which followed an extension of the teaching and learning in the classroom that give students the opportunity to enhance, consolidate and practice knowledge, skills and values in the classroom. There are a lot of activities that can be benefitted by them such as music classes, tuition and so on. These activities can make them to develop their cognition and as a result, they will get good results in examinations held in schools. Their time will also be fulfilled with good activities that will not spoil their future. Malaysian education programme has been done so that children will have a balanced development from physical, emotion, social and religion aspects.

Moriana (2006) has selected 12 schools to assess the relationship between achievement and involvement in additional after-school activities either at school or outside school, such as music classes, badminton, tuition and so forth. The results obtained once again shows that when students are involved in additional activities to obtain excellent results in academics. Quinn (2004) stated academic after-school activities can enrich the understanding, enrichment and academic reinforcement. Starting from the indoor games like chess to sports activities can expose students to new relationships and ideas explored. In addition, after-school activities to reduce alcohol consumption and acceptance among peers are a growing trend (Fredricks, 2005).

Darling, Caldwell and Smith (2005) has been doing research on the effects of after-school activities for students' academic achievement and found that students who are actively involved in academic activities that are beneficial after-hours can improve their cognition development in the academic field in which they can obtain excellent results. This is because they move their minds active and alert. 
Crane (2010) has stated that after-school activities can improve students' academic equivalent of social skills. Students tend to spend more time with their peers at school and their communication skills will improve.

Ngajikin et al. (2006) in a study conducted on students in University Technology Malaysia showed that most of the Malay and non Malay students involved active in extra-curricular activities add value degree and nature of employment also have higher cumulative achievement. The average student is aware of the benefits derived from co-curricular activities can help them build self to face the working world.

According to Santrock (2007), the balancing term recommendation (equilibration) by Piaget (1969) is a mechanism to explain how students move from one level of thinking to another level. Removal of thinking occurs when students have a conflict of cognition or imbalance (disequilibrium) in an attempt to understand the surrounding world. At this stage of formal operations (11 years and above), students begin to think of abstract principles such as democracy, the recognition and thinking. They start out thinking in concrete and specific examples that are made in the concrete operational stage.

According to Coon and Mitterer (2007), older adolescents are capable of inductive and deductive reasoning. They are able to understand mathematics, physics, philosophy, psychology and other abstract systems. Academic activities after school are good and effective as these enable students to consolidate assimilation and accommodation in their cognition. When they are constantly exposed to a positive activity, they can apply what they learn in the right direction. Positive developments taking place in the students help develop their cognition. Santrock (2007) explained, Scaffolding means changing the level of support. During the process of teaching and learning, teachers or friends for help or guidance of skilled control to suit the learning needs of students. When students learn new skills, teachers will use the 'direct instruction' (direct instruction), and when students have nearly become skilled, less guidance is given by the teacher. Dialogue is an important means used in scaffolding.

Hence, the aim of the research is to see whether academic activities after school will help secondary school students in their academic achievement and also the development of their cognition.

\section{Methodology}

This research will use Hermeneutic analysis and data was collected in the form of written essays, i.e. texts. It will analyse students' short essay to see about their academic activities after school that help their cognition development and it will lead to their success in academic. The method of this research is in the form of descriptive that analyses and interpret students essay. The sample of this research consists of 20 students from Form 1 till Form 3 in a secondary school. They were asked to write an essay about the activities they do after school hours. Researcher wanted to know the activities were carried out by the students whether they are involving in good or beneficial activities, especially after school hours.

\section{Findings}

This section is to show the outcome received based on the essays analysed. Interpretation of academic activities after school that help secondary school students in the cognition development through Hermeneutic analysis.

Table 1. Activities after school for Form 1 students

\begin{tabular}{cl}
\hline Respondents $(R)$ & Activities \\
\hline R1 & Homework, study, tuition, module paper \\
R2 & Homework, tuition, revision \\
R3 & Revision, homework \\
R4 & Revision, exercises
\end{tabular}

Form 1 students do various activities to improve their cognition development after school.

On average, they are involved in similar activities. Respondent 1 took the time to do homework, studying, going to tuition and make a paper module. Respondent 2 are involved in three activities such as to complete school work, going to tuition and doing revision. Respondent 3 used to study and finish school work, while Respondent 4 concentrated on the review and did the training provided by the teacher.

They are all Form 1 students. They have sat the Primary School Assessment Test (UPSR) last year. Their habit of studying for the examinations is good while they were in Form One. This shows their good attitude towards academic inclination. They are diligent students so that they meet when they have to do their homework, studying, going to tuition, do a paper module, to revise and practice of school subjects. 
Table 2. Activities after school for Form 2 students

\begin{tabular}{cl}
\hline Respondents $(R)$ & Activities \\
\hline R5 & Extra class, revision \\
R6 & Mathematic exercise, study \\
R7 & Tuition, study, revision, notes, homework \\
R8 & Study, internet, exercise, television \\
R9 & 'prep' class, study \\
R10 & Revision, tuition \\
R11 & Homework, study, exercise, revision \\
\hline
\end{tabular}

Based on Table 2, a total of seven students from Form 2 of the respondents written their answers as in the essay form.

Respondent 5 stated that she lives in a dormitory and she was engaged in additional classes, religion, review and learning sessions conducted at the hostel. Respondent 6 was more focused on maths and reading training. Respondent 7 went to tuition, study, review, and make notes and do homework to improve the cognition. Respondent 8 also took the time to read, learn to use the internet, exercise and watch television that was broadcast education. Respondent 9 also was a student living in the hostel. So, she goes go to the 'prep' class and does most essential works. Respondent 10 is preparing for exams and goes to tuition, while Respondent 11 does the homework, studying, practicing and preparing for exams.

Table 3. Activities after school for Form 3 students

\begin{tabular}{ll}
\hline Respondents $(R)$ & Activities \\
\hline R12 & Study, homework, exercise \\
R13 & Television, revision \\
R14 & Homework, tuition \\
R15 & Revision, tuition, homework \\
R16 & Homework, extra class, study \\
R17 & Study, revision \\
R18 & Revision, exercise \\
R19 & School work, revision \\
R20 & School work, study, revision
\end{tabular}

Table 3 involves nine students from Form 3. The findings of the respondents start with Respondent 12. Respondent 12 have chosen to study, does homework and make training as academic activities after school. Further more, Respondent 13 would watch television and prepare for exams. Respondent 14 will does homework and goes to tuition. Respondent 15 stated that she will make revision, goes to tuition and does housework. Respondent 16 chose homework, extra classes and learn to do after school activities. Respondent 17 studies and prepares for exams. While Respondent 18 will review and practice. Respondent 19 does homework and exams. Finally, Respondent 20 makes school work, learn and study.

\subsection{Analysis of Secondary School Students Academic Activities That Can Help Students' Cognition Development}

\subsubsection{Form 1 Students (First Respondent-Fourth Respondent)}

As a result of the interpretation of academic activities after school that helps secondary school students in the development of their cognition through analysis of Hermeneutics can be stated that these are students who have a passion to study. They will spend time with as possible in their own way to learn after school. Respondents consisted of students from Form 1 to Form 3. These groups of Form 1 students were considered to be smart students, while they were in primary school. They passed the Primary School Assessment Test (UPSR). So, they had the habit of practicing a lot of academic work while they were in primary school. They continued this habit while they were Form 1. They have the passion for academic inclination by doing a lot of activities which were directed towards academic achievement. The main thing that they practice after school is doing a lot of homework. The teachers train them to be hardworking in all the activities after teaching and learning process. 
Purpose of asking them to give homework is as additional training and strengthening as a result of the subjects taught in school. They do work at home so they do not stop learning in schools but continue learning at home. Learning itself is an effective method of learning where students learn by their own pace. It paves way for them to learn better. Students learn by themselves to strengthen the existing understanding of the subjects studied in school. Respondent 1 chose Saturday and Sunday to go to tuition. By two days involvement in tuition classes, students can spend the best to learn with the help of the tutor. Students also select a number of subjects to go to tuition such as Malay Language, Science and Mathematics for students who feels weak in all three of these subjects and need crucial attention. Student will also use the time available to complete the paper as possible with the module paper selected as additional learning modules. Students prepare themselves for additional training to further specialize in subject contents. Respondent 2 completes the tasks entrusted by the teacher. Respondent 2 chose night to go to tuition as an additional learning and do not forget to revise to update the information about what they have learned on that day. Further more, respondents will not forget to study and practice to recall what they have learned and not to forget. This method will also increase the knowledge and will also test the understanding of the subject contents.

\subsubsection{Form 2 Students (Respondent 5-Respondent 11)}

Respondent 5 to respondents 11 consisted of seven students. Cognition acquiring level of education is difficult compared to the previous level. One respondent gave more attention to mathematical practice every day, so as not to easily forgotten. Reading is very important method of learning. School student should always read the books, especially books with subjects that need to memorize facts. Respondent stated that she would go to tuition for mathematics because she is weak in this subject. Class teachers encourage her to make a lot of practice by doing Mathematics. Moreover, she is a poor student in maths. She needed teacher's help to better understand Mathematics. Although she is weak, but she is keen to learn and was given confidence by the teacher. Respondent will also take time to learn by herself. When she learns, she can look back on what she had learnt and make her own notes. When students make their own notes, they will be able to remember the contents better. Learning such a way, will enhance the respondent to remember for a long time. Students also prefer during night to revise after they settled the homework at day time. Not many students initiate to take the time to make their own lessons notes. Notes in the form of a mind map or brief notes will enable students to understand and remember what is written. Not forgetting to complete homework as the task given by the teacher. There were respondents who choose to study at the library. In the library, there are many reference books which can be referred by students. The quiet environment in the library helps learning more effective. Respondent 8 came from a poor family, and this does not mean she is in despair to learn. She took the initiative to learn and the most appropriate place is the library.

Respondent 8 keen to learn geography as its reference books facilitates the understanding of the respondent to learn. When she understood what she learns, she will maintain in order to obtain good results in exams because she already knew about the studying techniques to learn. Young people are more vulnerable to the internet. Internet can be used to retrieve reference materials quickly. Respondent 8 also makes training to strengthen the understanding of the topics she has learned by watching television as part of education. Watching television is another way of acquiring knowledge. Students do not feel burdened to learn. They only watch television but at the same time they are learning. Respondent 9 is a student living in fully residential school. She always goes to prep class. Students living in residential school follows tight schedule provided by the hostel for that prep class for homework assignments and preparing for exams. At night, Respondent 9 studies. Respondent 9 will learn first topic to be studied to understand better. When teachers teach the next day Respondent 10 will begin to make her own study time for exams. Respondent 9 made preparations to revise the examination from the beginning and not in a rush. In addition, she will go to tuition to learn what the teacher taught and reinforced by training and when do not understand, she may ask the teacher. Respondent 11 allocates time for homework given by teachers. Work is performed in accordance with the stipulated time. In addition, this respondent is self-disciplined to learn. She made a timetable in order to carry out her learning strategies. At night, Respondent 11 chose to make the history revision to enable respondent to understand history better. Students make a lot of training to be able to answer very well during the examination. Respondents have the habit to revise at night before bed so as not to miss the practice.

\subsubsection{Form 3 Students (Respondent 12-Respondent 20)}

Respondent 12 - Respondent 20 consists of Form 3 students. They study hard at home because they are involved with major public examination. Studying in school is not enough as they should be skilled and fully understand what they have learned. They will review the lessons at home, make additional training and go to tuition to learn. Their time is filled with studying because they have to understand the notes and in all the subjects studied in 
order to be properly ready to answer during the examination. When really tired, they will rest and play to get rid of stress and thus create a healthy mind and body. Respondent 12 study on time to concentrate all subjects and continue the next day with subjects that couldn't be focussed on previous day. Practice is a very good way of understanding and is an effective tool. They tend to practice past year exam question papers to prepare effectively to face the exams. Respondent 13 learn by watching the Astro broadcast (Channel 603). Learning to use visual and verbal without using the book as the main aspect of learning. In addition, respondents will revise the lessons carefully. Respondents could recall what they have learned to get more understanding. Respondent 15 used to practice doing homework before to bed. On average, Respondents are enthusiastic for studying. Respondent 15 used to spend time fully. He does not waste time but grabs the opportunity to learn. Respondent 19 would revise the lesson by reading reference books and practice every day. Tuition is the main method of learning for Form 3 students. They chose to go to tuition centres for getting more information. These tuition centres usually consist of those with experience teachers who taught for many years. They know the entire marking schemes of public examinations. Respondent 14 stated that she likes to learn from the same person to understand the subjects easily. Respondent 20 has different learning patterns of compared to the other respondents. This respondent will play to maintain the healthy body with playing his favourite game. When students do physical activity, they will be keeping their body and mind fit. With this, respondent can concentrate on her studies.

\section{Conclusion}

This study aims to conclude the academic activities carried out by the Pantai Remis Secondary School students after school time. Students from Form 1 to Form 3 were chosen as respondents. An amount of 20 written essays as texts were collected after students given a time frame set by the teacher. These texts were analyzed using Hermeneutics analysis method, i.e. an interpretive way of analysing the texts. The academic activities carried out by the school students after school time conducted to identify the types of after-school academic activities that can help students' cognition development. All positive activities carried out by students after school time benefits them.

Government's efforts to create a generation of healthy young and competent for the developed countries towards the achievement of the year 2020 should be taken seriously. Therefore, we have a responsibility to create a generation of students who are balanced physically, emotionally, spiritually and intellectually in order to have healthier life styles. The school, parents and communities should work together so that secondary school students can be exposed to positive activities so as to produce a healthy and active generation in terms of cognition.

\section{References}

Coon, D., \& Mitterer, J. O. (2007). Introduction to Psychology: Gateways to Mind and Behavior. Belmont, CA: Thomson Wadsworth.

Crane, C. E. (2010). An after school program to reduce teen violence, Recidivism and prepare teens for the workplace in Douglas County, Georgia. Public Health theses. Paper 144. Dimuat turun. Retrieved October 21, 2011, from http://digitalarchive.gsu.edu/iph_theses/144

Darling, N., Caldwell, L. L., \& Smith, R. (2005). Participation in school-based extracurricular activities and adolescent adjustment. Journal of Leisure Research, 37, 51-76.

Fredricks, J. A. (2005). Developmental benefits of extracurricular involment: Do peer characteristics mediate the link between activities and youth outcomes? Journal of Youth and Adolescence, 34(6), 507-520.

Kamus Dewan. (2005). Kamus Dewan. (Edisi Baru). Kuala Lumpur: Dewan Bahasa dan Pustaka.

Moriana, J. A., Alos, F., Alcala, R., Pino, M. J., \& Hermzo, J. (2006). Extra-curricular activities and academic performance in secondary students. Journal of Research in Educational Psychology, 4(1), 35-46. http://dx.doi.org/10.1007/s10964-005-8933-5

Ngajikin, N. H., Murad N. A., \& Esa M. R. M. (2006). Kesan Aktiviti Kelab dan Persatuan Pelajar Universiti Teknologi Malaysia Ke Atas Pencapaian Akademik. Kajian Ilmiah. Skudai: Universiti Teknologi Malaysia.

Piaget, J. (1969). The Psychology of The Child. New York: International Universities Press.

Quinn, J. (2004). Multiple needs, multiple strategies: How a after school programs contribute to academic success. The legislative Gazette: The Weekly Newspaper of the New York State Government.

Santrock, J. W. (2007). Educational Psychology. New York: McGraw-Hill. 